Jurnal Bahan Alam Terbarukan

\title{
Pengaruh Penambahan Em4 (Effective Microorganism-4) Pada Pembuatan Biogas Dari Eceng Gondok dan Rumen Sapi
}

\section{Megawati $^{1 \bowtie}$ dan Kendali Wongso $\mathrm{Aji}^{2}$}

\section{DOI 10.15294/jbat.v3i2.3696}

Prodi Teknik Kimia, Fakultas Teknik, Universitas Negeri Semarang, Indonesia

\section{Article Info}

Sejarah Artikel:

Diterima Oktober 2015

Disetujui Desember 2015

Dipublikasikan Desember 2015

Keywords:

Biogas, cow's rumen, EM4

(Effective Microorganism-4), water hyacinth.

\begin{abstract}
Abstrak
Eceng gondok (Eichornia crassipes) merupakan tanaman yang menjadi limbah perairan dan keberadaannya belum banyak dimanfaatkan. Kandungan selulosa, hemiselulosa, dan lignin di dalamnya dapat dimanfaatkan menjadi biogas melalui proses fermentasi. Penelitian ini mengkaji pengaruh EM4 (Effective Microorganism-4) terhadap massa, nilai kalor, dan kecepatan pembentukan biogas dari eceng gondok. Percobaan dilakukan dalam anaerobic digester berukuran 4 liter, bahan baku yang digunakan adalah eceng gondok, rumen sapi, dan air dengan variabel penambahan EM4 sebesar 1\% dan 0\%. Fermentasi dilakukan secara batch dengan pengukuran gas (temperatur, tekanan, dan massa) setiap 7 hari sekali sampai hari ke-35. Sebelum proses fermentasi, dilakukan pengujian terhadap rasio $\mathrm{C} / \mathrm{N}$ campuran bahan baku. Pembakaran gas dilakukan untuk membuktikan gas yang didapat mengandung metana. Hasil Penelitian menunjukkan bahwa rasio C/N untuk variabel dengan penambahan EM4 1\% sebesar 5,33 dan rasio $\mathrm{C} / \mathrm{N}$ untuk variabel dengan penambahan EM4 $0 \%$ sebesar 7. Jadi, penambahan EM4 dapat menurunkan rasio C/N. Sementara itu, hasil fermentasinya memperlihatkan bahwa EM4 memperkecil produksi biogas meskipun proses pembentukannya cepat. Massa total biogas yang didapat pada variabel EM4 1\% sebesar 1,1 g dan variabel EM4 0\% sebesar 1,55 g. Tekanan biogas mengalami fluktuasi (pada variabel EM4 1\% sebesar 35,6 cmH2O, sedangkan pada variabel EM4 0\% sebesar 40,6 cmH2O). Berdasarkan simulasi menggunakan chemical process simulator software, diketahui heating value biogas sebesar $39.180 \mathrm{~kJ} / \mathrm{kg}$.
\end{abstract}

\begin{abstract}
Water hyacinth (Eichornia crassipes) is a plant that becomes waste and its existence has not been widely used. Content of cellulose, hemicellulose, and lignin in it can be converted into biogas through a process of fermentation. Study examines the effect of EM4 (Effective Microorganism-4) on the mass, heating value, and the rate of formation of biogas from water hyacinth. An experiments were performed in anaerobic digesters size of 4 liters, the raw material used is water hyacinth, cow's rumen, and water with variable of EM4 addition of $1 \%$ and $0 \%$. Fermentation was carried out in batch condition with gas measurement (temperature, pressure, and mass) every 7 days until the 35 th day. Before fermentation, the $C / N$ ratio of raw material mixture was analyzed. The gas was burnt to prove that the obtained gas containing methane. Results showed that the $C / N$ ratio for the variable with the addition $E M 41 \%$ is 5.33 and $C / N$ ratio for the variable with the addition $E M 40 \%$ is 7 . Thus, the addition of EM4 can reduce C/N ratio. Despite the formation process is rapid, the results showed that EM4 reduce the biogas production. Total mass of biogas obtained at variable EM4 1\% is $1.1 \mathrm{~g}$ and variable EM4 $0 \%$ is 1,55 g. Biogas pressure is fluctuated (at variable EM4 $1 \%$ is $35.6 \mathrm{cmH} 2 \mathrm{O}, \mathrm{EM} 40 \%$ is $40.6 \mathrm{cmH} 2 \mathrm{O}$ ). Based on simulation using the chemical process simulator software, it is known that biogas heating value is $39,180 \mathrm{~kJ} / \mathrm{kg}$.
\end{abstract}

(C) 2015 Semarang State University 


\section{PENDAHULUAN}

Dalam beberapa tahun terakhir ini, Indonesia menghadapi berbagai permasalahan energi. Beberapa penyebabnya adalah terus meningkatnya harga minyak mentah diiringi dunia yang dengan subsidi BBM yang tinggi. Untuk mengatasi permasalahan energi tersebut, alangkah baiknya kita melakukan konversi dan konservasi energi sesuai dengan Perpres No.5 tahun 2006 tentang Kebijakan Energi Nasional (KEN). KEN bertujuan mewujudkan ketahanan energi dengan sasaran pada tahun 2025, diperoleh energi yang bersumber dari minyak sebesar $20 \%$, gas $30 \%$, batu bara $33 \%$, dan energi baru dan terbarukan sebesar 17\%. Melihat kondisi seperti itu, perlu dilakukan kajian terhadap energi alternatif yang cocok dan dapat diproduksi di Indonesia (Batubara, 2014).

Salah satu energi alternatif yang cocok dan dapat diproduksi di Indonesia adalah biogas. Biogas merupakan gas mudah terbakar yang dihasilkan dari proses fermentasi bahan-bahan organik oleh bakteri anaerob. Prinsip pembuatan biogas adalah adanya dekomposisi bahan organik secara anaerobik (tertutup dari udara bebas) untuk menghasilkan gas yang sebagian besar berupa gas metana $\left(\mathrm{CH}_{4}\right)$ dan karbondioksida $\left(\mathrm{CO}_{2}\right)$. Proses dekomposisi anaerobik dibantu oleh sejumlah mikroorganisme, terutama bakteri penghasil metan.

Serangkaian proses yang terjadi pada pembentukan biogas meliputi hidrolisis, asidogenesis, asetogenesis, dan metanogenesis. Berikut adalah tahap-tahap pembentukan biogas dalam anaerobic digestion (Al Saedi dkk, 2008):

Hidrolisis

Secara teoritis, langkah pertama dalam proses pembentukan biogas adalah hidrolisis. Pada tahap hidrolisis ini, kompleks bahan organik (polimer) didekomposisi menjadi unit yang lebih kecil (mono dan oligo). Selama proses tersebut, polimer seperti karboidrat, lipid, asam nukleat dan protein diubah menjadi glukosa, gliserol, purin dan pirimidin. Mikroorganisme hidrolitik akan mensekresi enzim hidrolitik, mengubah polimer menjadi senyawa sederhana berdasarkan persamaan seperti yang ditunjukkan di bawah ini:

Lipid

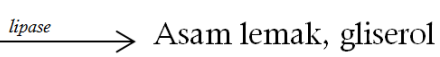

(ii)

Polisakarida $\stackrel{\text { selulase, selobiase, xilanase, amilase }}{\longrightarrow}$ Monosakarida

Lipid $\longrightarrow$ lipase $\longrightarrow$ Asam lemak, gliserol

(iii)
Proses hidrolisis membutuhkan mediasi exo-enzim yang diekskresi oleh bakteri fermentatif. Produk yang dihasilkan dari proses hidrolisis lebih lanjut diuraikan oleh mikroorganisme yang terlibat dan digunakan untuk proses metabolisme mereka sendiri. Walaupun demikian proses penguraian anaerobik sangat lambat dan menjadi terbatas dalam penguraian limbah selulolitik yang mengandung lignin. Pada proses ini, bakteri pengurai asam menguraikan senyawa glukosa sesuai dengan reaksi berikut (Mosey (1983) dalam jurnal Manurung (2004)):

$$
\begin{aligned}
\mathrm{C}_{6} \mathrm{H}_{12} \mathrm{O}_{6}+2 \mathrm{H}_{2} \mathrm{O} \longrightarrow & 2 \mathrm{CH}_{3} \mathrm{COOH}+2 \mathrm{CO}_{2} \\
& +4 \mathrm{H}_{2} \text { (As. Asetat) } \\
\mathrm{C}_{6} \mathrm{H}_{12} \mathrm{O}_{6} \longrightarrow & \mathrm{CH}_{3} \mathrm{CH}_{2} \mathrm{CH}_{2} \mathrm{COOH}+2 \mathrm{CO}_{2} \\
+ & 2 \mathrm{H}_{2} \text { (As. Butirat) } \\
\mathrm{C}_{6} \mathrm{H}_{12} \mathrm{O}_{6}+2 \mathrm{H}_{2} \longrightarrow & 2 \mathrm{CH}_{3} \mathrm{CH}_{2} \mathrm{COOH} \\
& +2 \mathrm{H}_{2} \mathrm{O} \text { (As. Propinoat) (vi) }
\end{aligned}
$$

\section{Asidogenesis}

Selama proses asidogenesis, produk hidrolisis dikonversi oleh bakteri asidogenik menjadi substrat metanogen. Gula sederhana, asam amino, dan asam lemak terdegradasi menjadi asetat, karbondioksida dan hidrogen (70\%) serta menjadi Volatile Fatty Acid (VFA) dan alkohol (30\%).

Asetogenesis

Selama proses asetogenesis, produk dari asidogenesis yang tidak dapat diubah secara langsung menjadi metana oleh bakteri metanogen akan diubah menjadi substrat metanogen. VFA dan alkohol dioksidasi menjadi substrat metanogen seperti asetat, hidrogen dan karbondioksida. Produk hidrogen meningkatkan tekanan parsial hidrogen, hal ini dianggap sebagai produk limbah dari proses asetogenesis dan menghambat metabolisme bakteri asetogenik. Tahap selanjutnya adalah metanogenesis, selama proses metanogenesis hidrogen akan diubah menjadi metana. Asetogenesis dan metanogenesis biasanya sejajar, sebagai simbiosis dari dua kelompok organisme. Metanogenesis

Produksi metana dan karbondioksida dari produk antara dilakukan oleh bakteri metanogen, $70 \%$ dari metana yang terbentuk berasal dari asetat, sedangkan $30 \%$ sisanya dihasilkan dari konversi hidrogen $(\mathrm{H})$ dan karbondioksida $\left(\mathrm{CO}_{2}\right)$, menurut persamaan berikut:

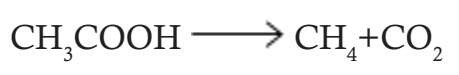

$2 \mathrm{H}_{2}+\mathrm{CO}_{2} \longrightarrow \mathrm{CH}_{4}+2 \mathrm{H}_{2} \mathrm{O}$ 
Metanogenesis merupakan langkah penting dalam seluruh proses pencernaan anaerobik, karena metanogenesis merupakan reaksi biokimia paling lambat dalam proses. Proses metanogenesis sangat dipengaruhi oleh kondisi operasi. Beberapa contoh yang mempengaruhi proses metanogenesis adalah komposisi bahan baku, perbandingan makanan, temperatur, dan nilai $\mathrm{pH}$. Overload digester, perubahan temperatur, dan masuknya oksigen dalam jumlah besar dapat mengakibatkan penghentian produksi metana.

Dalam suatu proses pembentukan biogas di dalam digester yang memanfaatkan bakteri sebagai sarana untuk memecah senyawa polimer (dalam hal ini adalah karbohidrat, lemak, dan protein) diperlukan media tambahan untuk membantu mempercepat proses, dan salah satu media yang dapat digunakan untuk membantu mempercepat proses tersebut adalah EM4 (Efective Microorganisme-4) (Sundari, 2012). EM4 merupakan media berupa cairan yang berisi mikroorganisme yang dapat memecah senyawa polimer (dalam hal ini adalah karbohidrat, lemak, dan protein) menjadi senyawa monomernya. Penelitian akan pengaruh EM4 terhadap proses fermentasi yang pada akhirnya akan berpengaruh terhadap massa, nilai kalor, dan kecepatan pembentukan biogas perlu dilakukan, mengingat semakin cepat pembentukan biogas, akan semakin banyak sumber energi yang dihasilkan, sehingga produksi biogas akan semakin tinggi. Hal tersebut akan sangat menguntungkan bagi masyarakat karena semakin tinggi produksi biogas, maka kebutuhan bahan bakar minyak sebagai sumber energi dapat diminimalisir.

\section{METODE}

Penelitian ini dibagi menjadi dua tahap, yaitu tahap produksi biogas dan tahap pengujian biogas. Tahap produksi biogas dimulai sejak penyiapan alat hingga selesai fermentasi, dan tahap pengujian biogas merupakan serangkaian pengujian untuk mengetahui parmeter biogas.

\section{Tahap Produksi Biogas}

Sebelum penelitian dimulai, beberapa alat perlu dipersiapkan untuk mendukung lancarnya proses produksi biogas. Persiapan tersebut meliputi merangkai digester (Gambar 1), menguji kebocoran digester, dan menyiapkan seperangkat alat yang digunakan untuk menguji parameter biogas. Digester dibuat dari pipa PVC yang banyak dijual dipasaran, berukuran panjang $50 \mathrm{~cm}$, dengan diameter 4 in. Volume digester sebesar 4 L, kapasitas substrat yang digunakan sebesar $75 \%$, atau setara dengan 3 L. Disisakan ruang sebesar $25 \%$ atau setara dengan $1 \mathrm{~L}$, untuk penyimpanan gas sementara sebelum dipanen. Seperangkat alat yang digunakan untuk pengujian meliputi manometer, termometer, korek api, selang dan sejumlah kran. Manometer yang digunakan adalah manometer pipa $\mathrm{U}$, dengan isian berupa aquades. Manometer tersebut digunakan untuk mengetahui besarnya tekanan biogas yang didapat berdasarkan perbedaan ketinggian fluida pada pipa U. Termometer yang digunakan adalah termometer raksa, termometer tersebut digunakan untuk mengukur temperatur biogas yang didapat. Korek api digunakan untuk melakukan uji pembakaran biogas. Selang dan sejumlah kran digunakan untuk mengatur aliran biogas ke balon dan manometer. Setelah digester siap digunakan, tahap selanjutnya adalah menyiapkan bahan baku dan memformulasikannya sesuai variabel. Pertama-tama eceng gondok dicacah hingga halus, lalu ditimbang sesuai variabel, kemudian dimasukkan ke dalam digester bersamaan dengan bahan yang lainnya. Setelah semua bahan masuk ke dalam digester, kemudian dilakukan pengadukan dengan menggoyangkan digester ke kanan dan ke kiri sebanyak 5 kali. Setelah homogen, kemudian digester disimpan untuk melanjutkan proses fermentasi. Proses fermentasi dilakukan selama 35 hari, terhitung sejak semua bahan dicampurkan. Selama proses fermentasi, setiap minggunya biogas yang didapat dilakukan pengecekan parameter meliputi massa, tekanan, dan temperatur biogas. Variabel tetap yang ditetapkan adalah kondisi operasi temperatur kamar, tekanan $1 \mathrm{~atm}$, air $2 \mathrm{~L}$, kotoran sapi $750 \mathrm{~mL}$, dan eceng gondok $300 \mathrm{~g}$. Variabel berubah yang digunakan adalah penambahan EM 1\% dan EM 4 $0 \%$.

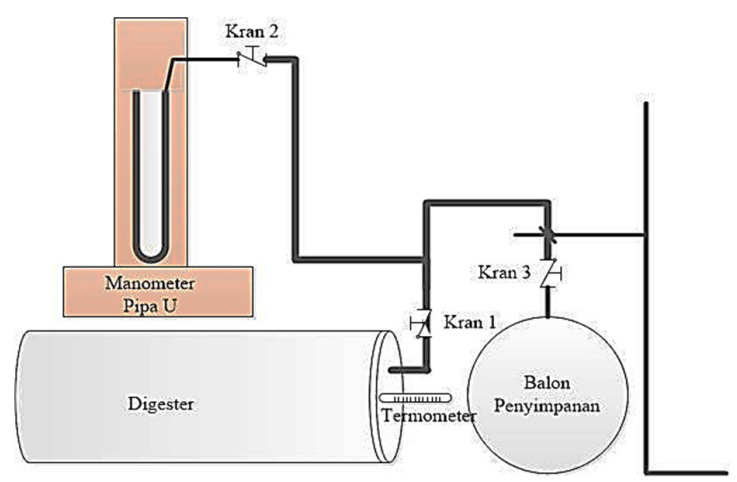

Gambar 1. Rangkaian Alat Penelitian

\section{Tahap pengujian biogas}

Biogas yang didapat dialirkan ke dalam balon, menggelembungnya balon menunjukkan adanya aliran massa gas ke dalam balon. Ke- 
mudian dilakukan pengukuran tekanan dengan menggunakan manometer pipa $U$ berisi aquades. Beda ketinggian dalam pipa menunjukkan besarnya tekanan per $\mathrm{cmH}_{2} \mathrm{O}$. Sebelum dilakukan pemanenan gas, terlebih dulu balon sebagai tempat gas ditimbang. Kemudian gas baru dialirkan ke dalam balon. Gas yang berada dalam balon ditutup rapat-rapat dan dilepaskan dari digester dan manometer pipa U, kemudian ditimbang bersamaan dengan gas yang masih berada di dalamnya. Massa menunjukkan berat balon ditambah berat gas. Pengukuran temperatur dilakukan dengan menancapkan termometer ke digester. Kemudian didiamkan selama beberapa menit hingga temperatur konstan. Kemudian dilakukan pencacatan. Pengukuran temperatur tersebut berdasarkan pemuaian raksa yang terlihat dalam skala termometer. Uji pembakaran dilakukan dengan mengalirkan gas yang terdapat pada balon ke sumber panas. Sumber panas yang digunakan adalah korek api. Gas dikeluarkan sedikit demi sedikit berdasar bukaan pada kran. Ketika dibakar, biogas akan menampakkan api yang berbeda dari korek api yang digunakan. Api yang semakin besar dan berwarna biru menunjukkan adanya gas metan yang terkandung dalam biogas.

\section{HASIL DAN PEMBAHASAN}

\section{Pengaruh EM4 terhadap Rasio C/N}

Percobaan ini diawali dengan mencampurkan bahan baku sesuai variabel, kemudian memasukkannya ke dalam digester untuk mengalami proses fermentasi secara anaerob. Sebelum dimasukkan ke dalam digester, sebagian sampel diambil untuk dilakukan analisis terhadap kadar C-organik dan N-total. Berdasarkan variabel yang ditetapkan terdapat dua sampel, yaitu sampel pertama dari campuran eceng gondok dan rumen sapi dengan pengenceran air, dan sampel kedua dari campuran eceng gondok, rumen sapi, dan EM4 sebanyak 1\% dengan pengenceran air. Hasil analisis tersebut disajikan padaTabel 1.

Tabel 1 tentang pengaruh EM4 terhadap Rasio $\mathrm{C} / \mathrm{N}$ menunjukkan bahwa penambahan
EM4 dapat menurunkan rasio $\mathrm{C} / \mathrm{N}$, penurunan tersebut mengindikasikan bahwa EM4 mengandung nitrogen, sehingga ketika ditambahkan, maka kadar nitrogen akan bertambah dan rasio $\mathrm{C} / \mathrm{N}$ akan menurun. Meningkatnya kandungan nitrogen ini diduga disebabkan oleh semakin banyak volum EM4 yang ditambahkan sehingga jumlah mikroba sebagai agen pendekomposisi bahan organik akan semakin banyak pula, akibatnya nilai total $\mathrm{N}$ anorganik dalam senyawa $\mathrm{NH}_{4}^{+}$dan $\mathrm{NO}_{3}^{-}$sebagai hasil dari dekomposisi bahan organik (protein) akan semakin meningkat pula (Kurniawan, 2013). Selain itu, penurunan unsur C disebabkan oleh aktivitas mikroorganisme dalam menghasilkan energi. Hal tersebut diperkuat oleh Sundari (2012) yang menyatakan bahwa karbon merupakan suatu kandungan pada tanaman yang berfungsi sebagai sumber energi, dan nitrogen merupakan salah satu unsur untuk pertumbuhan vegetatif dan pembentukan protein.

Rasio $\mathrm{C} / \mathrm{N}$ merupakan perbandingan dari pasokan energi mikroba yang digunakan terhadap nitrogen untuk sintesis protein (Elmi, 2012). Penurunan rasio $\mathrm{C} / \mathrm{N}$ dapat mempercepat proses fermentasi, karena rasio $\mathrm{C} / \mathrm{N}$ yang terlalu tinggi akan menyebabkan nitrogen terkonsumsi sangat cepat oleh bakteri-bakteri metanogen untuk memenuhi kebutuhan protein dan tidak akan lagi bereaksi dengan sisa karbonnya. Namun, jika rasio $\mathrm{C} / \mathrm{N}$ sangat rendah, nitrogen akan dibebaskan dan terkumpul dalam bentuk $\mathrm{NH}_{4} \mathrm{OH}$ (Ludfia, 2012). Kecepatan fermentasi tersebut berbanding lurus dengan kecepatan produksi biogas, sehingga semakin cepat proses fermentasi, maka semakin cepat produksi biogas. Pada penelitian Yulistiawati (2008), EM4 ditambahkan pada substrat dengan tujuan untuk memperpendek fase adaptasi atau lag phase dari mikroorganisme saat permulaan proses degradasi, sehingga dari segi waktu proses pendegradasian akan lebih cepat. Selain itu, tujuan lain penambahan EM4 untuk mengantisipasi keterbatasan jenis mikroba alami dan ketidakmampuan mikroba alami untuk mendegradasi beberapa senyawa toksik seperti senyawa pestisida yang terdapat pada bahan.

Tabel 1. Pengaruh Penambahan EM4 terhadap Rasio C/N

\begin{tabular}{ccccc}
\hline & \multirow{2}{*}{ Jenis } & \multicolumn{2}{c}{ C-organik } & N total \\
\cline { 3 - 4 } No. & Bahan & Spektrofotometri & Titrimetri & \\
\cline { 3 - 4 } & Baku & \multicolumn{2}{c}{$\%$} & \\
\hline 1. & EM4 0\% & 0.35 & 0.05 & 7 \\
2. & EM4 1 \% & 0.32 & 0.06 & 5.33 \\
\hline *) Analisis oleh Laboratorium Pupuk, BPTP Jawa Tengah
\end{tabular}




\section{Pengaruh EM4 terhadap Massa Biogas}

Tahapan percobaan selanjutnya setelah dilakukan pencampuran bahan baku adalah proses fermentasi dalam digester dan pengamatan pembentukan biogas yang dilakukan setiap hari mulai dari reaktor pertama hingga reaktor keempat selama 35 hari. Kemudian dilakukan pencatatan massa biogas yang terbentuk dalam gram dengan cara mengalirkan gas ke dalam balon yang sudah diberi pemberat. Menggelembungnya balon menunjukkan gas telah mengalir ke dalam balon. Data hasil pengamatan pembentukan biogas dapat dilihat pada Tabel 2.

Tabel 2. Pengaruh Penambahan EM4 terhadap Massa Biogas

\begin{tabular}{ccc}
\hline \multirow{2}{*}{$\begin{array}{c}\text { Waktu } \\
\text { (Minggu ke-) }\end{array}$} & \multicolumn{2}{c}{ Akumulasi Massa (g) } \\
\cline { 2 - 3 } & EM4 0\% & EM4 1\% \\
\hline 0 & 0 & 0 \\
1 & 0,4 & 0,59 \\
2 & 0,47 & 0,63 \\
3 & 1,29 & 0,76 \\
4 & 1,43 & 0,79 \\
5 & 1,55 & 1,1 \\
\hline
\end{tabular}

Berdasarkan Tabel 1 tentang pengaruh penambahan EM4 terhadap rasio $\mathrm{C} / \mathrm{N}$ dan Tabel 2 tentang pengaruh EM4 terhadap massa biogas, dapat disimpulkan bahwa EM4 dapat menurunkan rasio $\mathrm{C} / \mathrm{N}$ dan penurunan rasio $\mathrm{C} / \mathrm{N}$ tersebut berbanding lurus terhadap penurunan biogas yang dihasilkan. Hal tersebut diperkuat dalam penelitian Tubagus (2009) yang menyatakan bahwa rasio $\mathrm{C} / \mathrm{N}$ berpengaruh signifikan dalam produksi biogas. Dalam penelitian tersebut diperlihatkan semakin kecil rasio $\mathrm{C} / \mathrm{N}$, maka produksi kadar biogas yang dihasilkan semakin sedikit. Pada penelitian Yulistyawati (2008), rasio C/N berpengaruh terhadap biogas yang dihasilkan, produksi biogas terbesarnya didapat pada rasio $\mathrm{C} / \mathrm{N}$ sebesar 30 dengan gas yang dihasilkan sebesar $28,75 \mathrm{~mL}$ per $20 \mathrm{~mL}$ substrat, dan produksi terendah terjadi pada temperatur $30{ }^{\circ} \mathrm{C}$ dengan $\mathrm{C} / \mathrm{N}$ rasio 20 dengan biogas yang dihasilkan sebesar $8 \mathrm{~mL}$ per $20 \mathrm{~mL}$ substrat.

\section{Hubungan Massa dan Tekanan Gas}

Pengamatan terhadap tekanan biogas dilakukan untuk memperkuat data massa biogas, karena berdasar persamaan dari gas ideal PV = nRT, tekanan akan berbanding lurus dengan jumlah molnya, dan jumlah mol akan berbanding lu- rus dengan massa biogas. Tabel 3 menunjukkan bahwa tekanan terbesar terdapat pada variabel penambahan EM4 sebesar 0\%, pada minggu ketiga saat proses fermentasi yaitu sebesar $40,6 \mathrm{~cm}$ $\mathrm{H}_{2} \mathrm{O}$. Data tersebut berbanding lurus dengan data massa biogas pada variabel penambahan EM4 sebesar $0 \%$ pada minggu ketiga, yaitu sebesar 0,82 g. Pada teori gas ideal besarnya tekanan akan berbanding lurus dengan mol gas, dan besarnya mol dapat diketahui berdasar massa per berat massa atom. Hubungan antara massa dan tekanan biogas ditunjukkan oleh Gambar 2 dan 3.

Tabel 3. Data Pengamatan Tekanan Biogas

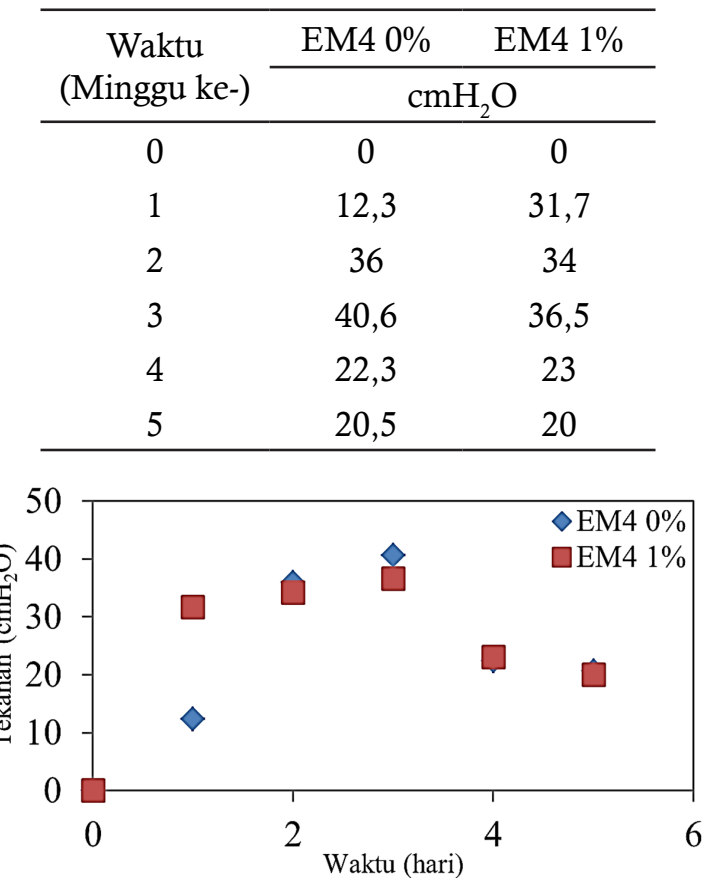

Gambar 2. Kurva Tekanan Biogas

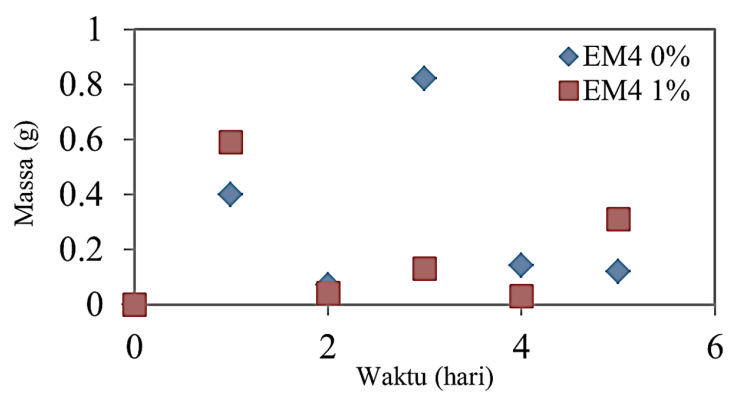

Gambar 3. Kurva Massa Biogas

Pada kurva yang terdapat pada Gambar 2 dan 3 tentang tekanan dan massa biogas, menunjukkan bahwa pada variabel penambahan EM4 0\% memiliki hubungan yang berbanding lurus. Profil tekanan terbesar dan massa terbesar terdapat pada minggu ketiga. Namun, pada variabel penambahan EM4 1\% memiliki hubungan yang 
tidak sesuai karena profil tekanan dan massa terdapat pada waktu yang berbeda (massa terdapat pada minggu pertama dan tekanan pada minggu ketiga). Hal tersebut memungkinkan adanya cairan yang ikut terbawa ke dalam balon pada saat pengambilan gas. Cairan tersebut dapat terbawa karena proses pengambilan gas dilakukan secara batch pada tekanan balon yang lebih kecil dari tekanan digester.

\section{Pengaruh Kondisi Operasi Reaktor terhadap Temperatur Biogas}

Kondisi operasi reaktor menjadi salah satu hal penting dalam proses fermentasi. Reaktor yang bagus harus mampu memberikan kondisi operasi yang stabil dan tidak terpengaruh oleh lingkungannya.

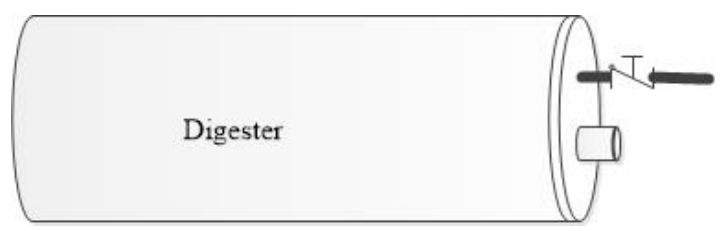

Gambar 4. Desain Reaktor

Pada penelitian ini, reaktor yang digunakan berbentuk tabung (Gambar 4), terbuat dari pipa PVC (Poly Vinil Chloride) yang banyak dijual dipasaran. Reaktor memiliki dua lubang. Lubang besar untuk memasukkan bahan dan lubang kecil untuk mengalirkan gas yang terbentuk. Kapasitas reaktor sebanyak 4 liter bahan cair, namun pada saat operasi, yang digunakan hanya $75 \%$ dari kapasitas reaktor, sehingga masih ada ruang bebas sebesar 25\% untuk menyimpan gas sementara. Desain reaktor mampu menahan temperatur pada kondisi kamar, yaitu sebesar $\pm 30^{\circ} \mathrm{C}$. Data pengamatan temperatur disajikan pada Tabel 4.

Tabel 4. Data Pengamatan Temperatur Biogas

\begin{tabular}{ccc}
\hline $\begin{array}{c}\text { Waktu } \\
\text { (Minggu ke-) }\end{array}$ & EM4 0\% & EM4 1\% \\
\hline 0 & 30 & 30 \\
1 & 30 & 30 \\
2 & 30 & 30 \\
3 & 30 & 30 \\
4 & 28 & 28 \\
5 & 28 & 29 \\
\hline
\end{tabular}

Tabel 4. menunjukkan bahwa temperatur operasi cenderung konstan pada temperatur $\pm 30{ }^{\circ} \mathrm{C}$. Temperatur tersebut merupakan kondisi mikroorganisme jenis mesofilik tumbuh dan berkembang secara optimal. Pada kondisi tersebut, perombakan bahan organik akan berlangsung baik, dengan diiringi kenaikan temperatur. Menurut Anugrah 2010, temperatur berpengaruh terhadap proses pencernaan anaerobik bahan organik dan produksi gas. Pencernaan berlangsung baik pada temperatur $30-40{ }^{\circ} \mathrm{C}$ untuk kondisi mesofilik dan pada temperatur $45-55$ ${ }^{\circ} \mathrm{C}$, temperatur $50-60^{\circ} \mathrm{C}$ untuk kondisi termofilik. Kecepatan fermentasi akan menurun pada temperatur di bawah $20^{\circ} \mathrm{C}$. Temperatur optimal kebanyakan bakteri mesofilik dicapai pada $35^{\circ} \mathrm{C}$, tetapi untuk bakteri termofilik pada temperatur $55^{\circ} \mathrm{C}$.

\section{Uji Pembakaran Biogas}

Uji pembakaran dilakukan dengan cara memasukkan gas dalam balon kosong, kemudian di ujung balon diberikan valve untuk membuka dan menutup aliran gas. Pembakaran dilakukan dengan menyalakan api menggunakan korek, kemudian valve dibuka sehingga gas bisa keluar, ketika gas keluar dan kontak dengan api, maka terjadilah pembakaran, kemudian api dimatikan dan gas masih tetap terbakar. Uji pembakaran juga menunjukkan bahwa gas berwarna biru, yang menandakan api cukup bagus untuk digunakan sebagai sumber energi. Tabel 5, tentang hasil uji pembakaran, menunjukkan bahwa semua gas hasil fermentasi pada setiap variabel dapat dibakar. Berarti, biogas yang dihasilkan mengandung metana $\left(\mathrm{CH}_{4}\right)$.

Tabel 5. Hasil Uji Pembakaran Biogas

\begin{tabular}{lccc}
\hline \multirow{2}{*}{ No. } & \multirow{2}{*}{$\begin{array}{c}\text { Jenis Bahan } \\
\text { Baku }\end{array}$} & \multicolumn{2}{c}{ Uji Pembakaran } \\
\cline { 3 - 4 } & Terbakar & Tidak Terbakar \\
\hline 1. & EM4 0\% & $\mathrm{V}$ & - \\
2. & EM4 1 $\%$ & $\mathrm{~V}$ & - \\
\hline
\end{tabular}

\section{Nilai Kalor (Heating Value) Biogas}

Pada pembuatan biogas, heating value merupakan parameter yang cukup penting untuk mengevaluasi biogas yang dihasilkan, sehingga heating value perlu dihitung guna mengetahui kemampuan biogas dalam menghasilkan energi. Dalam penelitian ini, heating value dihitung menggunakan chemical process simulation. Diperlukan beberapa asumsi untuk menghitung nilai biogas, antara lain adalah flow rate dan komposisi. Asumsi flow rate yang digunakan sebesar 1 $\mathrm{kg} / \mathrm{h}$ dan asumsi komposisi biogas yang digunakan berdasar penelitian Yonathan (2013). Hal ini karena pada penelitian tersebut bahan baku yang digunakan mirip dengan bahan baku peneli- 
tian ini, yaitu eceng gondok dan rumen sapi. Dari hasil simulasi menggunakan chemical process simulation, didapat nilai heating value sebesar 39.180 $\mathrm{kJ} / \mathrm{kg}$. Sementara itu, menurut Astals dan Joan (2011) heating value biogas berkisar antara 21.300 - $23.400 \mathrm{~kJ} / \mathrm{m}^{3}$ (29.583,3 - $\left.32.500 \mathrm{~kJ} / \mathrm{kg}\right)$. Jadi, selisih antara hasil simulasi dengan data pustaka $\pm 6.680 \mathrm{~kJ} / \mathrm{kg}$ atau sekitar $20 \%$.

\section{Kecepatan Pembentukan Biogas}

Kecepatan pembentukan biogas dihitung untuk mengetahui pengaruh EM4 dalam mendekomposisi bahan organik sehingga dapat mempercepat proses fermentasi. Berdasarkan Tabel 2 tentang pengaruh penambahan EM4 terhadap biogas, dapat disimpulkan bahwa kecepatan pembentukan terbesar terdapat pada variabel penambahan EM4 1\%, terjadi pada minggu pertama, yaitu sebesar 0,59 g/minggu. Kecepatan pembentukan biogas tersebut dipengaruhi oleh beberapa hal, salah satunya adalah kecepatan fermentasi bahan organik (pada reaktor tersebut mengandung 1\% EM4). Namun pada minggu selanjutnya hingga selesai kecepatan pembentukan biogas pada variabel penambahan EM4 1\% mulai berkurang.

Selama proses fermentasi, pembentukan biogas mengalami fluktuasi naik turun yang disebabkan oleh aktivitas mikroorganisme di dalam reaktor (lihat Gambar 3). Pada Gambar 3 tentang massa biogas, terlihat bahwa pada variabel penambahan EM4 1\% mencapai puncaknya pada minggu pertama. Hal tersebut mengindikasikan bahwa pada minggu pertama EM4 bekerja efektif untuk mendegradasi senyawa organik, kemudian pada minggu-minggu selanjutnya produksi biogas semakin berkurang. Sedangkan pada variabel penambahan EM4 0\% mencapai puncaknya pada minggu ketiga. Hal tersebut mengindikasikan bahwa proses degradasi lambat terjadi selama tiga minggu berturut-turut hingga terbentuk biogas yang paling banyak.

\section{SIMPULAN}

1. Tahapan Massa biogas yang dihasilkan dari variabel EM4 1\% sebesar 1,1 g dan massa biogas yang dihasilkan dari variabel EM4 0\% sebesar 1,55 g.

2. Penambahan EM4 dapat mengurangi rasio $\mathrm{C} / \mathrm{N}$ dan memperkecil massa biogas yang dihasilkan sebesar 29,032\%.

3. Penambahan EM4 dapat mempercepat proses fermentasi sehingga dapat mempercepat proses pembentukan biogas.

4. Heating value biogas sebesar $39.180 \mathrm{~kJ} / \mathrm{kg}$.

\section{DAFTAR PUSTAKA}

Al Saedi, T. dkk. 2008. Biogas Handbook. Denmark: University of Southern Denmark Esbjerg

Astals S., Mata J. 2011. Anaerobic Digestion. Departmen D'EnginyeriaQuimica, Universitat de Barcelona

Astuti, N, Soeprobowati, T.R, Budiyono. 2013. Potensi Eceng Gondok (Eichhornia crassipes (Mart.) Sol$m s$ ) Rawapening Untuk Biogas Dengan Variasi Campuran Kotoran Sapi. Workshop Penyelamatan Ekosistem Danau Rawapening. KLH dan UNDIP. Semarang.

Batubara Marwan, 2014. Setumpuk Masalah Energi yang Terjadi di Indonesia. Tersedia di: https:// bisnis.liputan6.com/read/2065578/setumpukmasalah-energi-yang-terjadi-di-indonesia. Akses: 14 september 2014.

Budiansyah Agus, dkk. 2011. Karakteristik Endapan Cairan Rumen Sapi asal Rumah Potong Hewan sebagai Feed Supplement. Jurnal ilmiah ilmu-ilmu Peternakan, Vol 14.1.

Haryati T. 2006. Biogas: Limbah Peternakan yang Menjadi Sumber Energi Alternatif. Balai Penelitian Ternak. Wartazoa Vol. 16.3.

Herawati Dewi A., dan Andang A. W. 2010. Pengaruh Pretreathment Jerami Padi pada Produksi Biogas dari Jerami Padi dan Sampah Sayur Sawi Hijau secara Batch. Jurnal Rekayasa Proses, Vol 4.1.

Kurniawan D., Sri K., dan Nimas M. S., 2013. Pengaruh Volumee Penambahan Effective Microorganism 4 (EM4) 1\% dan Lama Fermentasi Terhadap Kualitas Pupuk Bokashi dari Kotoran Kelinci dan Limbah Nangka. Jurnal Industria, Vol 2.1: $57-66$.

Manurung R. 2004. Proses Anaerobik Sebagai Alternatif Untuk Mengolah Limbah Sawit. Universitas Sumatra Utara.

Ruhimat M., dkk. 2009. Sosialisasi dan Pelatihan Pemanfaatan Biogas Skala Rumah Tangga sebagai Sumber Energi Alternatif Ramah Lingkungan di kampong Parabon desa Warnasari Kecamatan Pengalengan Kabupaten Bandung. Laporan Program Penerapan IPTEKS. Universitas Pendidikan Indonesia.

Sundari E., Ellyta S., dan Riko R. 2012. Pembuatan Pupuk organic Cair Menggunakan Bioaktivator biosca dan EM4. Prosiding SNTK TOPI.

Surung M. Y., 2008. Pengaruh Dosis EM4 (Effective Microorganism-4) dalam Air Minum Terhadap BeratBadan Ayam Buras. Jurnal Agrisistem, Vol 4.4.

Tim Pengabdian Masyarakat Dana DIPA. 2010. Pembuatan Digester Biogas Skala Rumah Tangga Menggunakan Kotoran Ternak Sapi. Universitas Sriwijaya.

Tubagus K. dkk. The Effect of C/N Ratios of a Mixture of Beef Cattle Feces and Water Hyacinth (Eichornia crassipes) on the Quality of Biogas and Sludge. Lucrări Ştiinţifice, Vol 55.

Wahyono Wahyono H. dan Nano S. 2012.Biogas Energi Ramah Lingkungan. Jawa Barat: Developing Collaborative Management of Cibodas Biosphere 
reserve.

Wahyuni Sri, 2013.Biogas, Energi alternative pengganti BBM, Gas, dan Listrik. Jakarta Selatan: PT Agromedia Pustaka.

Wati L., Yuni A., dan Dezi H. 2014. Pengaruh Volumee Cairan Rumen Sapi terhadap Bermacam Feses dalam Menghasilkan Biogas. Eksakta, Vol 1.

Windyasmara L., Ambar P., dan Lies M. Y. 2012. Pengaruh Jenis Kotoran Ternak Sebagai Substrat dengan Penambahan Serasah Daun Jati (Tectona grandis) terhadap Karakteristik Biogas pada Proses Fermentasi. Buletin Peternakan, Vol 36.1: 40 - 47.

Yenni, Yommi Dewilda, dan Serly M. S., 2012. Uji Pembentukan Substrat dari Substrat Sampah Sayur dan Buah dengan Ko-Substrat Limbah Isi Rumen Sapi. Jurnal Teknik Lingkungan UNAND 9 (1): 26-36.

Yonathan A., Avianda R. P., Bambang P., 2013. Produksi Biogas dari Eceng Gondok (Eichornia Crassipes): Kajian Konsistensi dan $\mathrm{pH}$ Terhadap Biogas Dihasilkan. Jurnal Teknologi Kimia dan Industri, Vol. 2.1: 211 - 215. 